\title{
電解還元法によるセレノニウム塩からのイリドの生成とその反応
}

\author{
森原 康滋, 松永 宏子, 洪 華, 饒村 修, 安藤 文雄, 頻纐 銃吾 \\ 中部大学工学部応用化学科（于 487-8501 春日井市松本町 1200）

\section{Generation of Selenonium Ylides from Selenonium Salts by Electrochemical Reduction and their Reactions}

\author{
Koji Morihara, Hiroko Matsunaga, Ka Kou, Osamu Niyomura, \\ Fumio ANDo, and Jugo KoKETSU
}

Department of Applied Chemistry, College of Engineering, Chubu University (1200 Matsumoto-cho, Kasugai 4878501, Japan)

Received May 15, 2009 ; Accepted June 1, 2009

\begin{abstract}
The cathodic reduction of selenonium salts bearing substituted benzyl, allyl and ethoxycarbonylmethyl group gave the ylides which were confirmed by the Corey-Chaykovsky reaction with benzaldehyde. In the absence of benzaldehyde, the [2,3] Sigmatropic rearrangement, coupling reaction, and olefin or cyclopropane formation via the ylides occurred in good yield. To elucidate the reaction mechanisms of the reactions of selenium ylides from selenium salts bearing allyl group, the theoretical density functional calculations were performed by using B3LYP with the $6-31+\mathrm{G}(\mathrm{d})$ basis set.
\end{abstract}

Key Words : Selenonium Salt, Ylide, Electrochemical Reduction, Rearrangement, Density Functional Calculation

\section{1 緒 言}

第 16 族元素オニウム塩は有機合成化学分野において，カ ルバニオン等価体として合成化学上重要な反応性を示すこと から，これまでその構造や反応に関して多くの研究がなされ てきた ${ }^{1-4)}$. 特に硫黄イリドは転位反応，カルベンの発生, 酸化反応，脱離反応およびカルボニル化合物との反応により， 新たな炭素骨格の形成に適した化合物として重要である。硫 黄イリドの反応としては，オレフィンを生成するWittig 反応 やエポキシドを生成するCorey-Chaykovsky 反応などが知ら れており，これまでこれらの反応の多くは塩基触媒を用いて 行なわれるのが主流であった。しかし，我々はテトラヒドロ チオフェンのオニウム塩からの硫黄イリドの簡便な合成と有 機合成への電気分解法の応用を目的として電解還元法 (EC 法）によるイリドの生成とその反応に関する研究を行なって きた ${ }^{5-9)}$.その結果, Scheme 1 に示すようにスルホニウム塩 からの電解還元反応による脱プロトン反応により, 穏和な反 応条件下でのイリドの合成に成功し，さらに，そこからの Sommelet-Hauser 転位反応が起こることを確認した ${ }^{10,11)}$. 本 研究では，構造が同じであるテトラヒドロセレノールを合成 しへテロ原子としてセレン元素を用い，各種置換基を有する セレノニウム塩を得た後，電解法によるセレノニウムイリド の生成とその反応性を検討した。

セレノニウム塩からのイリドの生成はScheme 2 に示すよ うな，置換基側にイリドを生成する安定イリド（A Route） とへテロ環側にイリドを生成する不安定イリド（B Route） が考えられ，2種類のイリドが生成すると想定される.
本論文では，各種置換基を有するイリドのCoreyChaykovsky 反応によるエポキシドの生成とセレノニウム塩 からの電解還元法により発生させたイリドから SommeletHauser 転位反応およびオレフィン化, シクロプロパン化反 応が起こる事を見出した. また, 電解還元ではオニウム塩が 還元されラジカル中間体が生成する事からラジカル開裂反応

Reaction of Sulfonium Ylide

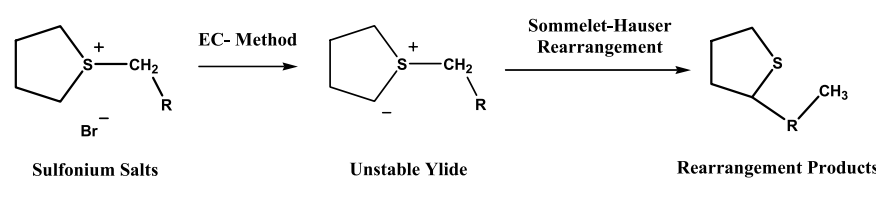

$\mathbf{R}=\mathbf{P h}$, Allyl

Scheme 1

Generation of Ylide by Electrochemical Method

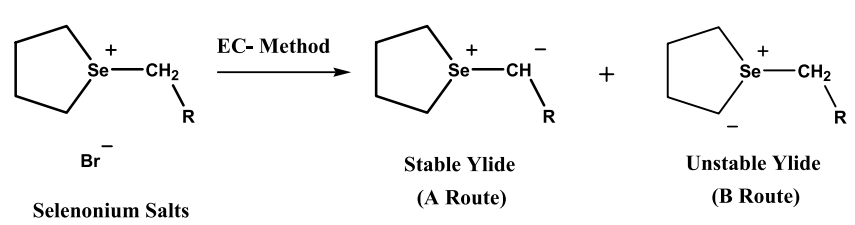

Scheme 2 
が観察される．さらに転位反応の反応経路の選択性およびそ の反応機構の解明のため， $6-31+\mathrm{G}$ (d) 基底関数系での B3LYP 密度汎関数法 ${ }^{12)}$ を用いた理論計算による反応経路の 検討を行なった。

\section{1 装置}

\section{2 実 験}

${ }^{1} \mathrm{H}-\mathrm{NMR} ，{ }^{13} \mathrm{C}-\mathrm{NMR}$ はTMS 用し，JEOL JNM-Aにて測定した。マススペクトルおよび GC 定量分析には島津 GCMS-QP2010を使用した。ガスクロ マトグラフィーのカラムには，DB-5 MS $(30 \mathrm{~m} \times 0.320$ $\mathrm{mm} \times 0.50 \mu \mathrm{m})$ を使用した。融点はSEIKOINSTRUMENTS TG-DTA SSC/5200 Hを使用した。IRスペクトルは島津 FTIR-8700にて測定した。電圧印加には日厚計測製ポテンシ ヨガルバノスタットNPGFZ 25-1-A を，また電気量測定には 日厚計測デジタルクーロンメーターNDCM-1を使用した 分離カラムクロマトグラフィーは分離液として $\mathrm{CHCl}_{3}$ を使用 し, Mallinckrodt silica（100 mesh）を用いた。水素のガス クロマトグラフィー分析は島津 GC-14Bを使用し，キャリヤ 一ガスとしてアルゴン，カラムとしてモレキュラーシーブ $5 \mathrm{~A}$ 用いた。

\section{2 反応試薬}

ベンジルブロミド， $\alpha$-ブロモ-p-キシレン，4-ニトロベンジ ルブロミド，4-シアノベンジルブロミド，3-ブロモプロペン， 4-ブロモ-2-メチル-2ブテン, ブロモ酢酸エチル, ベンズアル デヒド，拈よび過塩素酸テトラエチルアンモニウム塩は市販 品をそのまま用いた。溶媒として用いたアセトニトリルは市 販品を蒸留により精製して用いた。テトラヒドロセレノール は合成して使用した。その合成方法を以下に示す。

2. 2. 1 テトラヒドロセレノールの合成 $1 \mathrm{~L}$ のつ 口丸底フラスコに回転子を入れ，滴下ロートそして還流冷却 管を装着し，窒素ガス雲囲気下にした。フラスコにセレンパ ウダー $39.5 \mathrm{~g}(0.5 \mathrm{~mol})$ を入れ, 次に水 $300 \mathrm{~mL}$ で溶解させ た水酸化ナトリウム $100 \mathrm{~g}(2.5 \mathrm{~mol})$ を加えた.さらに, $0{ }^{\circ} \mathrm{C}$ で水冷しながら水 $300 \mathrm{~mL}$ で溶解させたロンガリット $154.2 \mathrm{~g} （ 1 \mathrm{~mol})$ をゆっくり滴下した。 反応終了後，反応混 合物を 1 時間加熱還流した。 その後，再び室温に戻し，水冷 しながら 1，4-ジブロモブタンを $108 \mathrm{~g}(0.5 \mathrm{~mol})$ 加え，相間 移動触媒として，テトラブチルアンモニウムブロミド $5 \mathrm{~g}$ を 加えた. 室温に戻した後, さらに 4 時間加熱還流を行ない, 再度, 室温で一夜攪拌, 放置した。 反応混合物を水蒸気蒸留 した後，有機層を分液し，無水硫酸ナトリウムによって脱水 乾燥させた。窒素ガス䨌囲気下で有機層を精留し目的物質を 得た。収率は 80 〜 83\%であった。

\section{2. 2 各種オニウム塩の合成 $50 \mathrm{~mL}$ 三角フラス} コに溶媒としてジエチルエーテルまたは THFを $30 \mathrm{~mL}$ 入, テトラヒドロセレノール $0.03 \mathrm{~mol}$ を溶解し, 各種ブロモ化ア ルキルを室温中，アルゴン䨌囲気下で当量加え十分に攪拌し た。 セレノニウム塩によって異なるが，1週間程度放置した 後, 沈殿したセレノニウム塩をジエチルエーテルにより洗浄, ろ過後, 減圧乾燥させ, 各々置換ベンジル基, アリル基, エ トキシカルボニル基を有するオニウム塩の計 7 種類（ $(\mathrm{a} \sim \mathrm{g})$ のオニウム塩を得た.

合成したテトラヒドロセレノールおよびオニウム塩の各種 スペクトルデータ，物性值を以下に示す。 テトラヒドロセレノール：無色透明液体；bp $138 \sim 140{ }^{\circ} \mathrm{C} /$ $1 \mathrm{~atm}$; IR (KBr Coat) 2977 (m), 2943 (s), 1437 (m), $1248(\mathrm{~m}), 850(\mathrm{~m}), 615(\mathrm{w}) \mathrm{cm}^{-1}$; ${ }^{1} \mathrm{H}$ NMR $(400 \mathrm{MHz}$, $\left.\mathrm{CDCl}_{3}\right) \delta=2.82(4 \mathrm{H}, \mathrm{t}, J=3.4 \mathrm{~Hz}), 1.93(4 \mathrm{H}, \mathrm{m})$ ppm ; ${ }^{13} \mathrm{C}$ NMR $\left(100 \mathrm{MHz}, \mathrm{CDCl}_{3}\right) \delta=33.2(\mathrm{~s}), 24.4(\mathrm{t}$, $J=25.7 \mathrm{~Hz}) \mathrm{ppm} ; \mathrm{MS} \mathrm{m} / \mathrm{z} 135\left[\mathrm{M}^{+}\right], 108$ (27), 94 (41), $55(80)$

1-(ベンジル)テトラヒドロセレノニウムブロミド $[\mathrm{a}] \mathrm{a}$ ：白 色固体； mp 115 $116^{\circ} \mathrm{C}$; IR (KBr Tablet) $2966(\mathrm{w})$, $2823(\mathrm{w}), 2086(\mathrm{w}), 1492(\mathrm{~m}), 1454(\mathrm{~m}), 1404(\mathrm{~m})$, $1311(\mathrm{w}), 1249(\mathrm{w}), 1230(\mathrm{w}), 1195(\mathrm{w}), 1126(\mathrm{w})$, $1068(\mathrm{w}), 1026(\mathrm{w}), 948(\mathrm{w}), 867(\mathrm{w}), 840(\mathrm{w}), 763$ (m), $702(\mathrm{~m}), 613(\mathrm{w}), 574(\mathrm{w}) \mathrm{cm}^{-1}$; ${ }^{1} \mathrm{H}$ NMR $(400$ $\left.\mathrm{MHz}, \mathrm{CDCl}_{3}\right) \delta=7.46-7.13(5 \mathrm{H}, \mathrm{m}), 4.1(2 \mathrm{H}, \mathrm{m}), 2.5$ $(4 \mathrm{H}, \mathrm{m}), 1.8(4 \mathrm{H}, \mathrm{m}) \mathrm{ppm} ;{ }^{13} \mathrm{C} \mathrm{NMR}(100 \mathrm{MHz}$, $\left.\mathrm{CDCl}_{3}\right) \quad \delta=137.6,130.1,129.1,128.2,42.9,42.2,29.7$ ppm

1-(4-メチルベンジル)-テトラヒドロセレノニウムブロミド [b] : 白色固体 ; mp 125-126 ${ }^{\circ} \mathrm{C}$; IR (KBr Tablet) $3045(\mathrm{w})$, $2970(\mathrm{w}), 2933(\mathrm{w}), 2831(\mathrm{w}), 1512(\mathrm{~m}), 1427(\mathrm{~m})$, $1413(\mathrm{~m}), 1396(\mathrm{~m}), 1313(\mathrm{w}), 1255(\mathrm{w}), 1147(\mathrm{w})$, $1126(\mathrm{w}), 1105(\mathrm{w}), 854(\mathrm{w}), 840(\mathrm{w}), 817(\mathrm{w}), 771$ $(\mathrm{w}), 582(\mathrm{~m}), 503(\mathrm{w}), 459(\mathrm{w}) \mathrm{cm}^{-1}$; ${ }^{1} \mathrm{H}$ NMR $(400$ $\left.\mathrm{MHz}, \mathrm{CDCl}_{3}\right) \delta=7.29-7.23(2 \mathrm{H}, \mathrm{m}), 7.15-7.13(2 \mathrm{H}, \mathrm{m})$, $4.48(2 \mathrm{H}, \mathrm{m}), 2.90-2.87(4 \mathrm{H}, \mathrm{m}), 2.36-2.34(4 \mathrm{H}, \mathrm{m})$, 2.01-1.99 (3H, m) ppm ; ${ }^{13} \mathrm{C} \mathrm{NMR}\left(100 \mathrm{MHz}, \mathrm{CDCl}_{3}\right)$ $\delta=138.3,129.4,128.9,127.6,44.8,43.0,30.5,21.2 \mathrm{ppm}$

1-(4-シアノベンジル)-テトラヒドロセレノニウムブロミド [c]：白色固体 ; mp 116-125 ${ }^{\circ} \mathrm{C}$; IR (KBr Tablet) 2962 (m), $2831(\mathrm{w}), 2361(\mathrm{w}), 2287(\mathrm{w}), 2230(\mathrm{~s}), 1929(\mathrm{w})$, $1782(\mathrm{w}), 1674(\mathrm{w}), 1605(\mathrm{~s}), 1504(\mathrm{~m}), 1416(\mathrm{~s})$, $1396(\mathrm{~s}), 1288(\mathrm{~m}), 1242(\mathrm{~m}), 1157(\mathrm{~m}), 1103(\mathrm{~m})$, $941(\mathrm{w}), 845(\mathrm{~s}), 772(\mathrm{w}), 590(\mathrm{~m}), 571(\mathrm{~m}) \mathrm{cm}^{-1}$; ${ }^{1} \mathrm{H}$ NMR $\left(400 \mathrm{MHz}, \mathrm{CDCl}_{3}\right) \delta=7.66-7.64(2 \mathrm{H}, \mathrm{d}, J=8.3$ $\mathrm{Hz}), 7.59-7.57(2 \mathrm{H}, \mathrm{d}, J=7.8 \mathrm{~Hz}), 4.53(2 \mathrm{H}, \mathrm{s}), 3.52-$ $3.36(4 \mathrm{H}, \mathrm{m}), 2.22-2.14(4 \mathrm{H}, \mathrm{m}) \mathrm{ppm} ;{ }^{13} \mathrm{C}$ NMR (100 $\left.\mathrm{MHz}, \mathrm{CDCl}_{3}\right) \delta=31.34,42.1,43.7,112.6,119.6,131.7$, $134.2, \quad 137.0 \mathrm{ppm}$

1-(4-ニトロベンジル)-テトラヒドロセレノニウムブロミド [d] : 黄色固体 ; mp 127-127 ${ }^{\circ} \mathrm{C}$; IR (KBr Tablet) 3097 (w), $2974(\mathrm{w}), 2918(\mathrm{w}), 2827(\mathrm{w}), 1963(\mathrm{w}), 1595(\mathrm{~m})$, $1514(\mathrm{~m}), 1398(\mathrm{w}), 1348(\mathrm{~m}), 1249(\mathrm{w}), 1195(\mathrm{w})$, $1145(\mathrm{w}), 1103(\mathrm{~m}), 1062(\mathrm{w}), 1010(\mathrm{w}), 946(\mathrm{w})$, $871(\mathrm{~m}), 806(\mathrm{w}), 757(\mathrm{w}), 707(\mathrm{~m}), 636(\mathrm{w}), 580$ $(\mathrm{w}), 459(\mathrm{w}) \mathrm{cm}^{-1} ;{ }^{1} \mathrm{H}$ NMR $\left(400 \mathrm{MHz}, \mathrm{CDCl}_{3}\right) \delta=$ 8.14-8.12 (2H, m), 7.59-7.57 (2H, m), 4.50 (2H, m), 3.44-3.36 (4H, m), 2.15-2.11 (4H, m) ppm ; ${ }^{13} \mathrm{C} \mathrm{NMR}$ $\left(100 \mathrm{MHz}, \mathrm{CDCl}_{3}\right) \delta=148.7,138.6,132.0,125.2,43.3$, $41.5,31.2 \mathrm{ppm}$

1-アリルテトラヒドロセレノニウムブロミド $[\mathrm{e}]$ ：白色固 
体 ; mp 147- $150{ }^{\circ} \mathrm{C}$; IR (KBr Tablet) 3078 (m), 2993 (m), $2943(\mathrm{~m}), 1843(\mathrm{w}), 1628(\mathrm{w}), 1435(\mathrm{w}), 1404(\mathrm{~m})$, $1308(\mathrm{~m}), 1246(\mathrm{~m}), 1192(\mathrm{~m}), 1119(\mathrm{~m}), 1084(\mathrm{~m})$, $1015(\mathrm{~m}), 953(\mathrm{w}), 922(\mathrm{~s}), 849(\mathrm{w}), 774(\mathrm{w}), 694$ (m), $579(\mathrm{w}) \mathrm{cm}^{-1} ;{ }^{1} \mathrm{H}$ NMR $\left(400 \mathrm{MHz}, \mathrm{CDCl}_{3}\right) \delta=$ 6.05-6.01 (1H, m), 5.53-5.11 (2H, m), 3.99-3.90 (2H, m), $2.89(4 \mathrm{H}, \mathrm{t}, J=13.4 \mathrm{~Hz}), 2.00(4 \mathrm{H}, \mathrm{t}, J=13.4 \mathrm{~Hz})$ ppm ; ${ }^{13} \mathrm{C} \mathrm{NMR}\left(100 \mathrm{MHz}, \mathrm{CDCl}_{3}\right) \delta=24.5,33.2,43.0$, $124.9,127.3 \mathrm{ppm}$

1-(2-ブテニル)テトラヒドロセレノニウムブロミド $[\mathrm{f}]$ ： 白色固体； mp 120-124 ${ }^{\circ} \mathrm{C}$; IR（KBr Tablet） 3005 (m), $2966(\mathrm{~m}), 2939(\mathrm{~m}), 1655(\mathrm{~m}), 1408(\mathrm{~s}), 1312(\mathrm{~s})$, $1254(\mathrm{~m}), 1200(\mathrm{~m}), 1123(\mathrm{~m}), 1097(\mathrm{~m}), 995(\mathrm{~s})$, $926(\mathrm{~m}), 845(\mathrm{~m}), 733(\mathrm{w}), 601(\mathrm{w}), 575(\mathrm{~m}) \mathrm{cm}^{-1}$; (E) -Isomer ; ${ }^{1} \mathrm{H}$ NMR $\left(400 \mathrm{MHz}, \mathrm{CDCl}_{3}\right) \delta=6.09-6.03$ $(1 \mathrm{H}, \mathrm{m}), 5.83-5.69(1 \mathrm{H}, \mathrm{m}), 3.39-3.36(2 \mathrm{H}, \mathrm{t}, J=5.6 \mathrm{~Hz})$, $2.88(4 \mathrm{H}, \mathrm{s}), 2.00(4 \mathrm{H}, \mathrm{s}) \mathrm{ppm} ;{ }^{13} \mathrm{C} \mathrm{NMR}(100 \mathrm{MHz}$, $\left.\mathrm{CDCl}_{3}\right) \delta=137.34,119.83,42.62,33.17,24.49,17.52 \mathrm{ppm}$

1-(3-メチル-2-ブテニル)テトラヒドロセレノニウムブロミ ド $[\mathrm{g}]$; 白色固体 ; $\mathrm{mp} 97-100{ }^{\circ} \mathrm{C}$; IR ( $\mathrm{KBr}$ Tablet) 3013 $(\mathrm{w}), 2966(\mathrm{~m}), 2862(\mathrm{~m}), 2314(\mathrm{~m}), 1980-1710(\mathrm{w})$, $1650(\mathrm{~s}), 1443(\mathrm{~s}), 1400(\mathrm{~s}), 1315(\mathrm{~m}), 1149(\mathrm{~m})$, $1026(\mathrm{~m}), 860(\mathrm{~s}), 764(\mathrm{~m}), 579(\mathrm{~m}) \mathrm{cm}^{-1} ;{ }^{1} \mathrm{H}$ NMR $\left(400 \mathrm{MHz}, \mathrm{CDCl}_{3}\right) \delta=5.55-5.51(1 \mathrm{H}, \mathrm{m}), 4.02(2 \mathrm{H}, \mathrm{d}$, $J=8.3 \mathrm{~Hz}), 2.89(4 \mathrm{H}, \mathrm{m}) 2.01(4 \mathrm{H}, \mathrm{m}), 1.78(3 \mathrm{H}, \mathrm{s})$, $1.73(3 \mathrm{H}, \mathrm{s}) \mathrm{ppm} ;{ }^{13} \mathrm{C} \mathrm{NMR}\left(100 \mathrm{MHz}, \mathrm{CDCl}_{3}\right) \delta=$ $145.33,112.76,42.43,33.19,25.67,24.52,19.16 \mathrm{ppm}$

エトキシカルボニルメチルセレノフェニウムブロミド [i]：白色固体 ; mp 127-130 ${ }^{\circ} \mathrm{C}$; IR (KBr Tablet) 2937 (s), $2889(\mathrm{~s}), 1713(\mathrm{~s}), 1469(\mathrm{~m}), 1398(\mathrm{~m}), 1298(\mathrm{~s})$, 1168 (s), $771(\mathrm{w}), 609(\mathrm{w}) \mathrm{cm}^{-1} ;{ }^{1} \mathrm{H} \mathrm{NMR}(400 \mathrm{MHz}$, $\left.\mathrm{CDCl}_{3}\right) \delta=4.19(2 \mathrm{H}, \mathrm{d}, J=6.8 \mathrm{~Hz}), 3.78(2 \mathrm{H}, \mathrm{s}), 2.83$ $(4 \mathrm{H}, \mathrm{s}), 1.95(4 \mathrm{H}, \mathrm{t}, J=2.9 \mathrm{~Hz}), 1.25(3 \mathrm{H}, \mathrm{t}, J=2.4$ $\mathrm{Hz}) \mathrm{ppm} ;{ }^{13} \mathrm{C} \mathrm{NMR}\left(100 \mathrm{MHz}, \mathrm{CDCl}_{3}\right) \delta=13.9,24.5$, 30.7, 33.2, 62.2, $166.1 \mathrm{ppm}$

\section{3 実験方法}

2. 3. 1 電解還元法（EC 法）恒温ジャケットで覆 ったガラス電解槽を用い, 各種セレノニウム塩 $(0.01 \mathrm{~mol})$ とベンズアルデヒド，もしくはセレノニウム塩のみを溶媒と してアセトニトリル（0.5 dL）に溶解した溶液を陰極相とし た. 陽極相としては陶器製のポーラスカップに溶媒としての アセトニトリル（0.1 dL）に電解質として過塩素酸テトラエ チルアンモニウム塩（0.01 mol）を溶解したものを使用した. 両相の電極として白金板 $\left(3 \times 1 \mathrm{~cm}^{2}\right)$ を用いた. 窒素雲囲 気下, $22^{\circ} \mathrm{C}$ 恒温槽中, 参照電極 $\mathrm{SCE}$ に対して $-2.5 \mathrm{~V}$ の条件 下にて，電解還元反応を行なった。電解還元電位は既報 ${ }^{13)}$ と同じ条件を用いた．陰極側からの水素発生はガスクロマト グラフィー分析により行なった. セレノニウム塩に対して 1 $\mathrm{F} / \mathrm{mol}$ 通電した後, 生成物をジエチルエーテルに溶解し, 同 量の水で洗浄し, 無機塩を除去した後, 有機層を取り出し無 水硫酸ナトリウムで乾燥させた. その後, エバポレーターに より溶媒除去後, GCMSにより反応直後の生成比率を確認し
た.そして，クロロホルムに溶解したシリカゲルを充填剤と するカラムクロマトグラフィーにより単離精製した。これら の構造は, 以下に示す物理的性質, スペクトルデータにより 決定した.

\section{4 反応生成物}

テトラヒドロセレノニル-2-メチルベンゼン［1］：黄色液 体 ; bp 266-268 ${ }^{\circ} \mathrm{C} / 1 \mathrm{~atm}$; IR (KBr Coat) 2927 (m), 2360 (m), 1850-1650 (w), $1488(\mathrm{~m}), 1434(\mathrm{~m}), 1238(\mathrm{~m})$, $1141(\mathrm{~m}), 756(\mathrm{~m}), 698(\mathrm{~m}) \mathrm{cm}^{-1} ;{ }^{1} \mathrm{H} \mathrm{NMR}(400 \mathrm{MHz}$, $\left.\mathrm{CDCl}_{3}\right) \delta=7.47-7.23(4 \mathrm{H}, \mathrm{m}, \mathrm{Ph}), 5.01(1 \mathrm{H}, \mathrm{d}, \mathrm{H}-4$, $J=5.4 \mathrm{~Hz}), 3.33-3.24(2 \mathrm{H}, \mathrm{m}, \mathrm{H}-1), 3.06(2 \mathrm{H}, \mathrm{m}, \mathrm{H}-2)$, $2.50(3 \mathrm{H}, \mathrm{s}, \mathrm{H}-11), 2.25-2.21(2 \mathrm{H}, \mathrm{m}, \mathrm{H}-3) \mathrm{ppm} ;{ }^{13} \mathrm{C}$ NMR $\left(100 \mathrm{MHz}, \mathrm{CDCl}_{3}\right) \delta=140.85,135.49,130.01$, $126.33,125.66,43.31,39.61,32.68,26.49,28.20,19.68$ ppm ; MS m/z $226\left[\mathrm{M}^{+}\right], 211$ (15), 183 (43), 145 (81), 131 (95), 117 (109), 91 (135)

テトラヒドロセレノニル-2,5-ジメチルベンゼン [2]：黄色 液体 ; bp 188-189 ${ }^{\circ} \mathrm{C} / 1 \mathrm{~atm}$; IR（KBr Coat） $3016(\mathrm{~m})$, $2920(\mathrm{~m}), 2854(\mathrm{~m}), 1850-1650(\mathrm{w}), 1612(\mathrm{~m}), 1500$ (m), $1438(\mathrm{~m}), 1238(\mathrm{~m}), 1142(\mathrm{~m}), 1107(\mathrm{~m}), 964$ (m), $810(\mathrm{~m}) \mathrm{cm}^{-1} ;{ }^{1} \mathrm{H} \mathrm{NMR}\left(400 \mathrm{MHz}, \mathrm{CDCl}_{3}\right) \delta=$ 7.30-6.83 (3H, m, H-6, 8, 9), $4.79(1 \mathrm{H}, \mathrm{H}-4)$, 3.12-3.04 $(2 \mathrm{H}, \mathrm{m}, \mathrm{H}-1), 2.77(2 \mathrm{H}, \mathrm{m}, \mathrm{H}-2), 2.24-2.22(6 \mathrm{H}, \mathrm{s}, \mathrm{H}-$ $11,12), 1.97-1.84(2 \mathrm{H}, \mathrm{m}, \mathrm{H}-3) \mathrm{ppm} ;{ }^{13} \mathrm{C} \mathrm{NMR}(100$ $\left.\mathrm{MHz}, \mathrm{CDCl}_{3}\right) \delta=140.65,138.76,135.17,130.13,128.91$, 127.08, 43.54, 39.77, 37.56, 32.89, 20.94, 19.34 ppm ; MS $\mathrm{m} / \mathrm{z} 240\left[\mathrm{M}^{+}\right], 225(15), 197$ (43), 159 (81), 145 (95), 131 (109), $117(123), 91$ (149)

4,4’ジシアノビベンジル [3]：白色固体； bp 190-193 ${ }^{\circ} \mathrm{C}$ /1atm ; IR (KBr Tablet) 3057 (m), 2933 (m), 2223 (s), 1850-1650 (w), $1602(\mathrm{~m}), 1504(\mathrm{~m}), 1413(\mathrm{~m}), 1176$ (m), $835(\mathrm{~m}), 577(\mathrm{~m}) \mathrm{cm}^{-1} ;{ }^{1} \mathrm{H} \mathrm{NMR}(400 \mathrm{MHz}$, $\left.\mathrm{CDCl}_{3}\right) \delta=7.50(4 \mathrm{H}, \mathrm{d}, J=8.1 \mathrm{~Hz}), 7.20(4 \mathrm{H}, \mathrm{d}, J=$ $14.8 \mathrm{~Hz}), 2.92(4 \mathrm{H}, \mathrm{s}) \mathrm{ppm} ;{ }^{13} \mathrm{C} \mathrm{NMR}\left(100 \mathrm{MHz}, \mathrm{CDCl}_{3}\right)$ $\delta=146.03,132.23,130.21,118.82,110.14,37.13 \mathrm{ppm}$; MS m/z $232\left[\mathrm{M}^{+}\right], 205(27), 175$ (57), 130 (102), 117 (115)

4,4'-ジニトロビベンジル [4]：黄色固体； bp 168-169 ㅇ /1atm ; IR (KBr Tablet) 3109 (w), 2939 (w), 2909 (w), $2361(\mathrm{w}), 1929(\mathrm{w}), 1798(\mathrm{w}), 1593(\mathrm{~m}), 1512(\mathrm{~s})$, 1339 (s), $1177(\mathrm{w}), 1107(\mathrm{~m}), 853(\mathrm{~m}), 787(\mathrm{w}), 752$ (m), $698(\mathrm{~m}), 617(\mathrm{w}) \mathrm{cm}^{-1} ;{ }^{1} \mathrm{H} \mathrm{NMR}(400 \mathrm{MHz}$, $\left.\mathrm{CDCl}_{3}\right) \delta=8.14(4 \mathrm{H}, \mathrm{d}, J=8.3 \mathrm{~Hz}, \mathrm{H}-3), 7.29(4 \mathrm{H}, \mathrm{d}$, $J=8.3 \mathrm{~Hz}), 3.08(4 \mathrm{H}, \mathrm{s}, \mathrm{H}-1) \mathrm{ppm} ;{ }^{13} \mathrm{C} \mathrm{NMR}(100 \mathrm{MHz}$, $\left.\mathrm{CDCl}_{3}\right) \quad \delta=36.84,148.15,123.71,129.29,145.97 \mathrm{ppm}$; $\mathrm{MS} \mathrm{m} / \mathrm{z} 272\left[\mathrm{M}^{+}\right], 226(46), 178$ (94), 136 (136)

2-アリルテトラヒドロセレノール [5]：黄色液体； bp 186-190 ${ }^{\circ} \mathrm{C} / 1 \mathrm{~atm}$; IR (KBr Coat) 3078 (m), 2974 (m), $2827(\mathrm{~m}), 2850(\mathrm{~m}), 1850-1650(\mathrm{w}), 1731(\mathrm{~m}), 1639$ (m), $1434(\mathrm{~m}), 1285(\mathrm{~m}), 1190(\mathrm{w}), 1114(\mathrm{~m}), 985$ (m), $914(\mathrm{~s}), 758(\mathrm{~m}), 694(\mathrm{~m}) \mathrm{cm}^{-1} ;{ }^{1} \mathrm{H}$ NMR $(400$ 
$\left.\mathrm{MHz}, \mathrm{CDCl}_{3}\right) \delta=7.28(1 \mathrm{H}, \mathrm{m}), 5.85-575(2 \mathrm{H}, \mathrm{m}), 5.09-$ $5.00(1 \mathrm{H}, \mathrm{m}), 3.60(2 \mathrm{H}, \mathrm{t}, J=6.1 \mathrm{~Hz}), 2.93(2 \mathrm{H}, \mathrm{d}$, $J=5.9 \mathrm{~Hz}), 2.21-2.13(2 \mathrm{H}, \mathrm{m}), 1.67-1.64(2 \mathrm{H}, \mathrm{m}) \mathrm{ppm}$; ${ }^{13} \mathrm{C}$ NMR $\left(100 \mathrm{MHz}, \mathrm{CDCl}_{3}\right) \delta=137.36,115.86,44.04$, 41.96, 38.90, 32.02, $25.18 \mathrm{ppm} ; \mathrm{MS} \mathrm{m} / \mathrm{z} 176\left[\mathrm{M}^{+}\right], 161$ (15), 135 (41), $107(69), 93$ (83)

2-(1,1-ジメチルアリル)テトラヒドロセレノール [6]：黄 色液体；bp109-114 ${ }^{\circ} \mathrm{C} / 1 \mathrm{~atm}$; IR（KBr Coat）2966（m), $2920(\mathrm{~m}), 2858(\mathrm{~m}), 1850-1650(\mathrm{w}), 1645(\mathrm{~m}), 1438$ $(\mathrm{s}), 1380(\mathrm{~m}), 1234(\mathrm{~m}), 1199(\mathrm{~m}), 1149(\mathrm{~m}), 1026$ (m), $860(\mathrm{~s}), 762(\mathrm{~m}) \mathrm{cm}^{-1} ;{ }^{1} \mathrm{H}$ NMR $(400 \mathrm{MHz}$, $\left.\mathrm{CDCl}_{3}\right) \delta=7.30(1 \mathrm{H}, \mathrm{m}, \mathrm{H}-7), 5.01-4.96(2 \mathrm{H}, \mathrm{m}, \mathrm{H}-8)$, 3.66-3.62 (1H, m, H-4) , 2.92-2.74 (2H, m, H-1), 2.302.05 (2H, m, H-2), 1.74-1.62 (2H, m, H-3), $1.11(6 \mathrm{H}, \mathrm{s}$, $\mathrm{H}-6,7) \mathrm{ppm} ;{ }^{13} \mathrm{C} \mathrm{NMR}\left(100 \mathrm{MHz}, \mathrm{CDCl}_{3}\right) \delta=148.23$, $111.45,57.62,39.70,33.86,33.29,26.15,25.68,24.75$ $\mathrm{ppm} ; \mathrm{MS} \mathrm{m} / \mathrm{z} 204\left[\mathrm{M}^{+}\right], 189$ (15), 175 (29), 161 (43), 148 (56), $135(69), 107(97), 93$ (111)

フマル酸ジエチル [7]：市販の標準物質と比較，同定した.

1,2,3-トリエトキシカルボニルシクロプロパン [8]： $(E)$ isomer only ; 黄色液体 ; bp $263-265{ }^{\circ} \mathrm{C} / 1 \mathrm{~atm}$; IR（KBr Coat) $3020(\mathrm{w}), 2990(\mathrm{~s}), 1730(\mathrm{~s}), 1320(\mathrm{~s}), 1180(\mathrm{~s})$, $1030(\mathrm{~s}), 855(\mathrm{~m}), 755$ (m) $\mathrm{cm}^{-1} ;{ }^{1} \mathrm{H}$ NMR (400 MHz, $\left.\mathrm{CDCl}_{3}\right) \delta=4.21-4.09(6 \mathrm{H}, \mathrm{m}), 2.72(3 \mathrm{H}, \mathrm{t}, J=5.9 \mathrm{~Hz})$, $1.28-1.20$ (9H, m) ppm ; ${ }^{13} \mathrm{C} \mathrm{NMR}\left(100 \mathrm{MHz}, \mathrm{CDCl}_{3}\right)$ $\delta=14.00,167.51,61.45,28.40,14.02,170.82,61.52$, $25.57 \mathrm{ppm} ; \mathrm{MS} \mathrm{m} / \mathrm{z} 258\left[\mathrm{M}^{+}\right], 213$ (45), $185(73), 112$ (146)

trans-スチルベン オキシド $[9]$ ：市販の標準物質と比較, 同定した.

trans-メチルスチルベン オキシド [10］：白色固体；mp $43-45^{\circ} \mathrm{C}$; IR ( $\mathrm{KBr}$ Tablet) $3038(\mathrm{~m}), 2960$ (m), 1850$1650(\mathrm{w}), 1517(\mathrm{~m}), 1450(\mathrm{~m}), 1271(\mathrm{~m}), 1109(\mathrm{~m})$, $1070(\mathrm{~m}), 817(\mathrm{~m}), 769(\mathrm{~m}), 738(\mathrm{~m}), 698(\mathrm{~m}) \mathrm{cm}^{-1}$; ${ }^{1} \mathrm{H} \mathrm{NMR}\left(400 \mathrm{MHz}, \mathrm{CDCl}_{3}\right) \delta=7.23-7.01(5 \mathrm{H}, \mathrm{m}), 6.96$ $(4 \mathrm{H}, \mathrm{d}, J=11.5 \mathrm{~Hz}), 3.61(1 \mathrm{H}, \mathrm{s}), 3.58(1 \mathrm{H}, \mathrm{s}), 2.10$ $(3 \mathrm{H}, \mathrm{s}) \mathrm{ppm} ;{ }^{13} \mathrm{C} \mathrm{NMR}\left(100 \mathrm{MHz}, \mathrm{CDCl}_{3}\right) \delta=137.11$, $132.58,129.31,128.91,128.18,128.02,126.47,125.19$, 62.47, 62.33, $20.84 \mathrm{ppm} ; \mathrm{MS} \mathrm{m} / \mathrm{z} 210\left[\mathrm{M}^{+}\right], 195(15)$, 181 (29), 166 (44), 152 (58), 103 (107)

3,4-エポキシ-4-フェニル-1-ブテン [11]：黄色液体 ; bp 148-150 ${ }^{\circ} \mathrm{C} / 1 \mathrm{~atm}$; IR (KBr Coat) 3085 (m), 3031 (m), $2991(\mathrm{~m}), 1850-1650(\mathrm{w}), 1637(\mathrm{~m}), 1496(\mathrm{~m}), 1456$ (m), $1440(\mathrm{~m}), 1388(\mathrm{~m}), 985(\mathrm{~m}), 925(\mathrm{~m}), 871(\mathrm{~s})$, $752(\mathrm{~s}), 698(\mathrm{~s}) \mathrm{cm}^{-1} ; \mathrm{MS} \mathrm{m} / \mathrm{z} 146\left[\mathrm{M}^{+}\right], 131$ (15), 117 (29), 105 (41), 89 (56) ; (E)-isomer ; ${ }^{1} \mathrm{H}$ NMR (400 $\left.\mathrm{MHz}, \mathrm{CDCl}_{3}\right) \delta=7.18-7.10(3 \mathrm{H}, \mathrm{m}, \mathrm{H}-6,7,8), 5.60-5.52$ $(1 \mathrm{H}, \mathrm{m}), 5.36-5.25(1 \mathrm{H}, \mathrm{m}, \mathrm{cis}), 5.17-5.07(1 \mathrm{H}, \mathrm{m}$, trans), $3.59(1 \mathrm{H}, \mathrm{d}, J=2.0 \mathrm{~Hz}), 3.19(1 \mathrm{H}, \mathrm{t}, J=2.2 \mathrm{~Hz})$ ppm ; ${ }^{13} \mathrm{C} \mathrm{NMR}\left(100 \mathrm{MHz}, \mathrm{CDCl}_{3}\right) \delta=134.94,131.92$, $128.23,127.95,125.24,119.02,62.59,59.87 \mathrm{ppm} ;(\boldsymbol{Z})$ isomer ; ${ }^{1} \mathrm{H} \mathrm{NMR}\left(400 \mathrm{MHz}, \mathrm{CDCl}_{3}\right) \delta=7.18-7.10(3 \mathrm{H}$, $\mathrm{m}), 5.60-5.52(1 \mathrm{H}, \mathrm{m}), 5.36-5.25(1 \mathrm{H}, \mathrm{m}, \mathrm{cis}), 5.17-5.07$ $(1 \mathrm{H}, \mathrm{m}, \mathrm{trans}), 4.05(1 \mathrm{H}, \mathrm{d}, J=4.4 \mathrm{~Hz}), 3.47(1 \mathrm{H}, \mathrm{t}$, $J=4.2 \mathrm{~Hz}) \mathrm{ppm} ;{ }^{13} \mathrm{C} \mathrm{NMR}\left(100 \mathrm{MHz}, \mathrm{CDCl}_{3}\right) \delta=136.83$, 131.92, 127.87, 127.44, 126.17, 121.57, 59.44, 58.47 ppm

2-メチル-5-フェニル-2-ペンテン-4-オール [12]：黄色液 体 ; bp $124-126{ }^{\circ} \mathrm{C} / 1 \mathrm{~atm}$; IR (KBr Coat) 3398 (m), 2972 (m), $2914(\mathrm{~m}), 1850-1750(\mathrm{w}), 1701(\mathrm{~m}), 1492(\mathrm{~m})$, $1450(\mathrm{~m}), 1363(\mathrm{w}), 1026(\mathrm{~m}), 758(\mathrm{~m}), 700(\mathrm{~m}) \mathrm{cm}^{-1}$; ${ }^{1} \mathrm{H}$ NMR $\left(400 \mathrm{MHz}, \mathrm{CDCl}_{3}\right) \delta=7.34-7.19(3 \mathrm{H}, \mathrm{m}, \mathrm{Ph})$, $5.13(1 \mathrm{H}, \mathrm{d}, J=6.8 \mathrm{~Hz}), 4.59(1 \mathrm{H}, \mathrm{t}, J=6.6 \mathrm{~Hz})$, 2.44$2.38(2 \mathrm{H}, \mathrm{m}), 1.80(1 \mathrm{H}, \mathrm{s}, \mathrm{OH}), 1.69(3 \mathrm{H}, \mathrm{s}$, trans $)$, $1.56(3 \mathrm{H}, \mathrm{s}$, cis $) \mathrm{ppm} ;{ }^{13} \mathrm{C} \mathrm{NMR}\left(100 \mathrm{MHz}, \mathrm{CDCl}_{3}\right)$ $\delta=144.17,135.18,128.13,127.17,125.72,119.17,73.89$, 38.04, 25.73, $17.78 \mathrm{ppm} ; \mathrm{MS} \mathrm{m} / \mathrm{z} 176\left[\mathrm{M}^{+}\right], 161$ (15), 143 (33), 128 (48), $117(59), 107(69), 103(73), 91$ (85)

2-フェニル-エチルグリシレート [13]：黄色液体 ；bp 162$163{ }^{\circ} \mathrm{C} / 1 \mathrm{~atm}$; IR (KBr Coat) 2982 (w), 2816（w), 1732 (s), $1701(\mathrm{~s}), 1597(\mathrm{w}), 1454(\mathrm{w}), 1285(\mathrm{w}), 1204(\mathrm{~s})$, $1119(\mathrm{~m}), 1026(\mathrm{w}), 826(\mathrm{w}), 748(\mathrm{~m}), 691(\mathrm{~m}) \mathrm{cm}^{-1}$; ${ }^{1} \mathrm{H}$ NMR $\left(400 \mathrm{MHz}, \mathrm{CDCl}_{3}\right) \delta=7.87-7.48(5 \mathrm{H}, \mathrm{m}, \mathrm{Ph})$, 4.22-4.16 $(2 \mathrm{H}, \mathrm{m}), 3.82(2 \mathrm{H}, \mathrm{s}), 1.27-1.24(3 \mathrm{H}, \mathrm{t}, J=$ $7.1 \mathrm{~Hz}) \mathrm{ppm} ;{ }^{13} \mathrm{C} \mathrm{NMR}\left(100 \mathrm{MHz}, \mathrm{CDCl}_{3}\right) \delta=191.82$, 133.99, 129.43, 129.24, 128.57, 128.03, 61.77, 60.86, 25.70, $13.54 \mathrm{ppm} ; \mathrm{MS} \mathrm{m} / \mathrm{z} 192\left[\mathrm{M}^{+}\right], 176$ (16), 156 (36), 147 (45), 135 (57), 118 (74), 107 (85), 91 (101), 79 (113)

なおこれらの反応生成物の構造と本稿で用いた化合物番号 を Fig. 1 に示した.

\section{5 計算方法}

計算にはGaussian03 分子軌道計算プログラムを用いた ${ }^{12)}$. 各平衡構造と遷移状態の構造は 6-31+G（d）基底関数系で のB3LYP密度汎関数法を用いて決定した. そして各最適化 構造で振動解析を行なった. その結果, 反応物と生成物の振 動はすべて正であり平衡構造として存在すること, また, 遷 移状態では唯一の虚の振動数を持つことを確認した. これら の計算と同一レベルでのエネルギー計算およびゼロ点エネル ギー補正を行なった。

またラジカル解離構造に関してはUB3LYPレベルで計算 を行なった。

\section{3 結果と考察}

\section{1 セレノニウム塩からのイリド生成とその反応}

各種セレノニウム塩から電解還元反応により発生させたセ レノニウムイリドの反応についてベンズアルデヒド存在下お よび非存在下で比較検討した. Table 1 に各反応における生 成物番号，収率および主反応を示した。

オニウム塩の電解還元法は一電子還元反応で進行すること が， $1 \mathrm{~F} / \mathrm{mol}$ の電気量を通電した時点でオニウム塩が全て消 失したこと, およびカソードから定量的に $\mathrm{H}_{2}$ ガスの発生が 


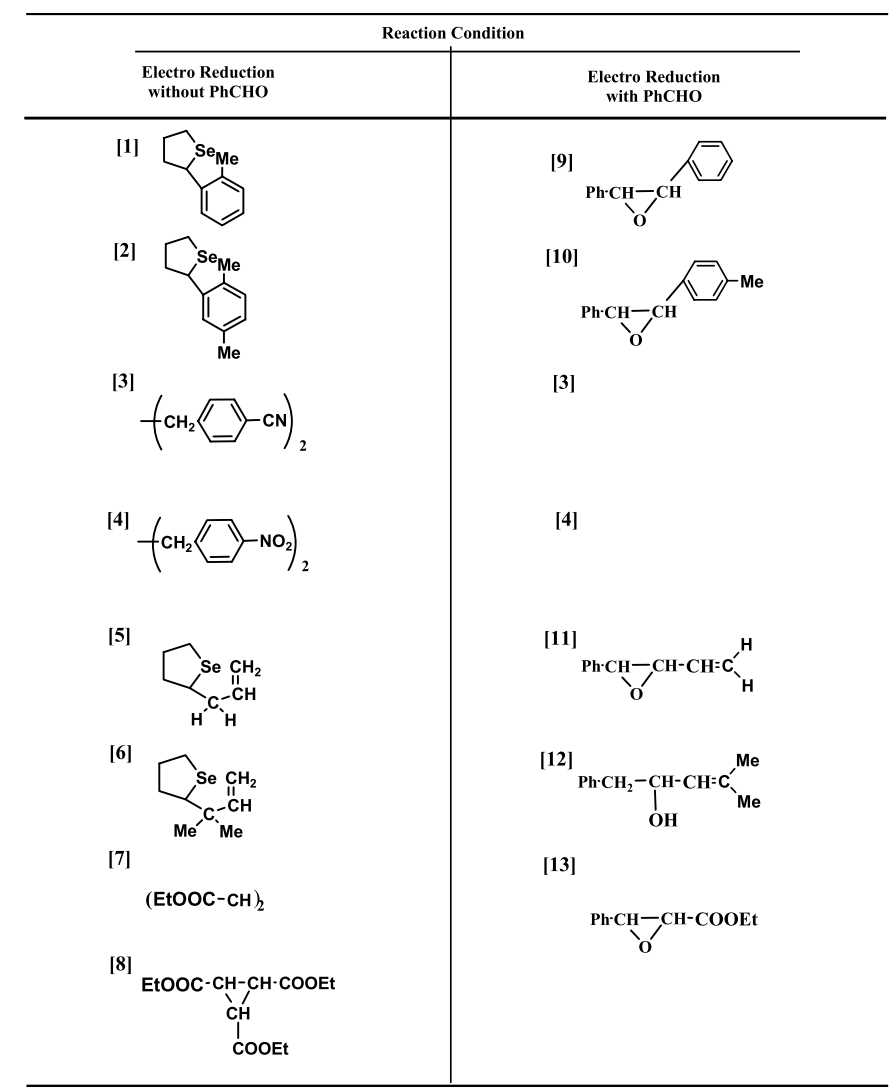

Fig. 1 Structures of the products from selenonium salts by electro chemical reduction with and without $\mathrm{PhCHO}$.

確認されることの $2 つ の$ 実験事実により支持される。また， これらの電解還元法による経路は, Scheme 3 に示したよう にセレノニウム塩から電解還元で生成するラジカル中間体を 経由して，安定イリド（以下イリドAとする）を生成する A route と不安定イリド（以下イリド Bとする）を生成する B route, そして, イリドからラジカル解裂を経る転位である C routeおよびイリドからカルベンを生成するD routeの 4 経 路が考えられる.

ベンズアルデヒド存在下では，へテロ原子上に電子供与性 の置換基を有するベンジル基を持つセレノニウム塩から発生 させたイリドでは，A routeの安定イリドを経由したCoreyChaykovsky 反応によるエポキシド生成物およびエポキシド
からのアルコール生成物が選択的に得られた．しかし，置換 ベンジル基を有するセレノニウム塩において, 強い電子求引 基である-CN基および- $\mathrm{NO}_{2}$ 基を有するオニウム塩において はC routeのベンジルラジカルからのカップリングによる二 量体が選択的に得られた。

ベンズアルデヒド非存在下の反応では A routeと B route そしてC routeの選択性は，へテロ原子上に有する置換基に 依存することが明らかとなった。置換ベンジル基を有するセ レノニウム塩では電子供与基である $\mathrm{R}_{1}=\mathrm{H}, \mathrm{Me}$ の時は $\mathrm{B}$ routeのイリドBからのSommelet-Hauser 型の転位反応が得 られた。一方，強い電子求引基である- $\mathrm{CN}$ 基および- $\mathrm{NO}_{2}$ 基 の場合では選択的にC routeのベンジルラジカルからのカッ プリング生成物が得られる結果であり，- $\mathrm{CN}$ 基および- $\mathrm{NO}_{2}$ 基のときでは, ベンズアルデヒド存在下の時と同様の反応性 を示した。これは，電子求引基である- $\mathrm{CN}$ 基および- $\mathrm{NO}_{2}$ 基 がラジカルを安定化させるため, 最初に生成するラジカル中 間体におけるベンジルラジカルの開裂反応が優先し, Scheme 5 に示すように反応は高選択的にC routeで進行し たと考えられる.

次にアリル基を持つセレノニウム塩からのイリドでは，ベ ンズアルデヒド存在下で, A routeの安定イリドAからのエ ポキシド生成物が得られる結果であり，また，この時アルコ

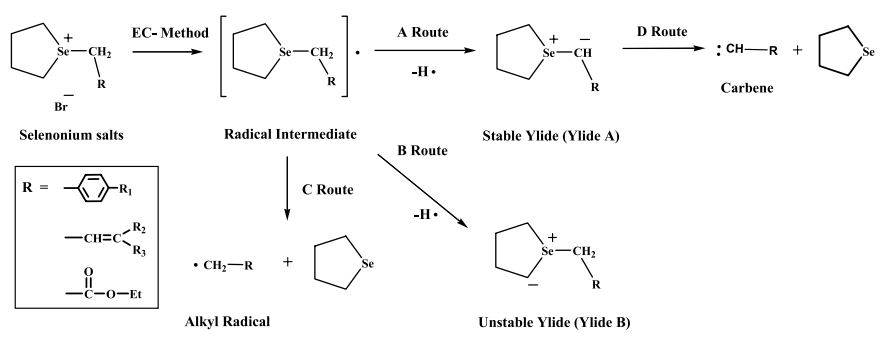

Scheme 3

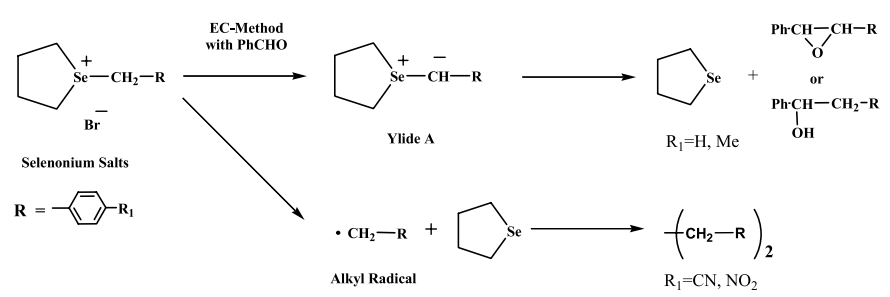

Scheme 4

Table 1 Products no, yield $(\%)$ and main reactions by electrochemical reduction of substituted methyltetrahydroselenonium bromide with and without benzaldehyde.

\begin{tabular}{|l|c|c|c|c|c|c|}
\hline \multirow{2}{*}{ Substituents } & \multicolumn{2}{|c|}{ Electrochemical reduction without Benzaldehyde } & \multicolumn{3}{|c|}{ Electrochemical reduction with Benzalhehyde } \\
\cline { 2 - 7 } & Prodact No. & Yield (\%) & Main reaction & Prodact No. & Yield (\%) & Main reaction \\
\hline $\mathrm{C}_{6} \mathrm{H}_{5-}$ & {$[1]$} & 31 & Rearrangement & {$[9]$} & 79 & Epoxide formation \\
\hline $4-\mathrm{CH}_{3} \mathrm{C}_{6} \mathrm{H}_{4^{-}}$ & {$[2]$} & 38 & Rearrangement & {$[10]$} & 63 & Epoxide formation \\
\hline $4-\mathrm{NCC}_{6} \mathrm{H}_{4^{-}}$ & {$[3]$} & 73 & Radical Coupling & {$[3]$} & 68 & Radical coupling \\
\hline $4-\mathrm{O}_{2} \mathrm{NC}_{6} \mathrm{H}_{4^{-}}$ & {$[4]$} & 94 & Radical Coupling & {$[4]$} & 72 & Radical coupling \\
\hline $\mathrm{CH}_{2}=\mathrm{CH}-$ & {$[5]$} & 50 & Rearrangement & {$[11]$} & 69 & Epoxide formation \\
\hline$\left(\mathrm{CH}_{3}\right)_{2} \mathrm{C}=\mathrm{CH}-$ & {$[6]$} & 70 & Rearrangement & {$[12]$} & 30 & Epoxide formation \\
\hline $\mathrm{EtO}_{2} \mathrm{C}-$ & {$[7],[8]$} & 36,21 & Carbene formation & {$[13]$} & 32 & Epoxide formation \\
\hline
\end{tabular}


ールまで還元された生成物 [12] が得られることも確認した. これは，電解還元法では水素をラジカルとして脱離させるた め, 脱離した水素ラジカルが溶液中に存在すると考えられる, その水素ラジカルとエポキシドがラジカル的な二次反応を引 き起こしたと想定される。またベンズアルデヒドの非存在下 での反応は $\mathrm{R}_{2}$ および $\mathrm{R}_{3}$ がともに $\mathrm{H}$ の場合， $\mathrm{R}_{2}$ および $\mathrm{R}_{3}$ とも にMe基の場合の全てにおいて $\mathrm{B}$ routeのイリドBからの Sommelet-Hauser 型の転位反応が得られた。

一方，安定イリドAを与え易いと考えられるエトキシカル ボニル基を有するセレノニウム塩ではオレフィンおよびシク ロプロパン形成による生成物が混在した。これらは電子求引 基を有する置換ベンジル基とは異なり，安定イリドAからの 開裂によるカルベンの発生による生成物であると考られる.

\section{2 反応経路およびその転位反応に関する理論計算}

アリル基を有するセレノニウム塩からの転位反応について の反応経路の選択性およびその反応機構の解明のため, B3LYP密度汎関数法による検討を行なった。ベンジル基, アリル基を有する硫黄イリド理論計算は既に報告した $6,7,11)$.

アリル基を有するセレノニウム塩から考えられる転位の反 応機構については, Scheme 8に示すように，安定イリドを 与える A routeではイリドAから TSA1を経由する [2,3]Sigmatropy 経路（Sommelet-Hauser転位），TSA2を経由す る [1,2]-Sigmatropy 経路 (Stevens 転位)，そしてTSA3を 経由してラジカル的に反応する Radical 開裂経路の 3 種類が 考えられる。同様に，B routeでもイリドBからのTSB1を 経由する [2,3]-Sigmatropy 経路，TSB2を経由する [1,2]Sigmatropy 経路，そしてTSB3 を経由する Radical経路の 3 種類が考えられる．アリル基を有するセレノニウム塩におい ては計算コスト上の理由およびアリル基を有する 3 種類のセ レノニウム塩において転位生成物が得られた実験事実より, $\mathrm{R}_{2}$ および $\mathrm{R}_{3}$ ともに $\mathrm{H}$ 基での計算を行なった。

これらの経路の各エネルギー值はScheme 8の括弧に示し

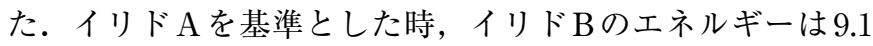
$\mathrm{kcal} / \mathrm{mol}$ となり，イリドAが安定であると考えられる。そ して，イリドAおよびイリド $\mathrm{B} の$ 両イリドは平衡で存在する
と考えられる.この事はベンズアルデヒド存在下でイリド $\mathrm{A}$ からのCorey-Chaykovsky 反応生成物のみが得られる一方， 転位生成物はイリドBからの生成物のみが得られる事から明

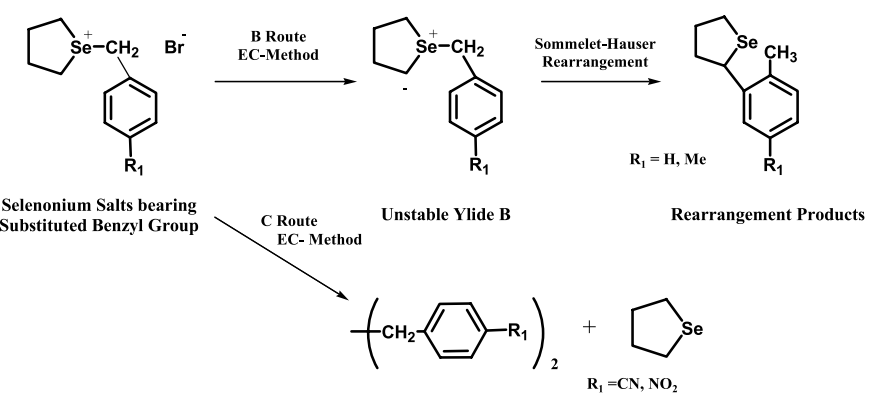

Scheme 5

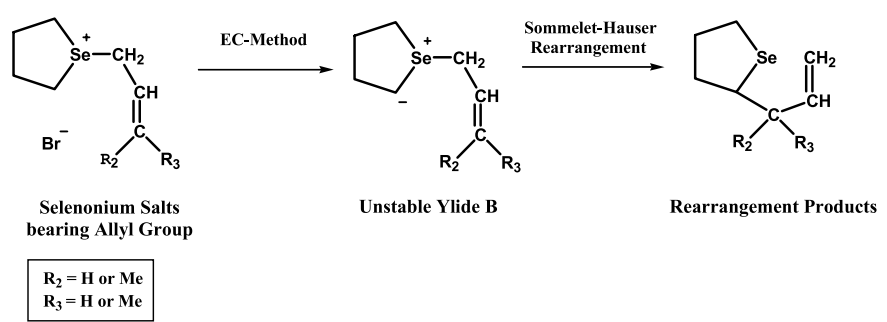

Scheme 6

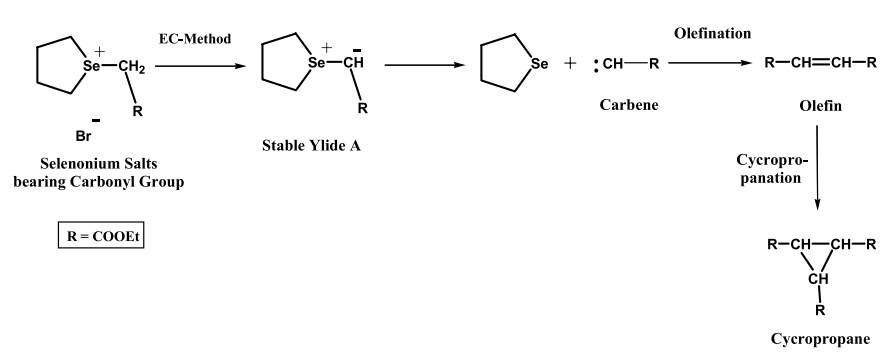

Scheme 7
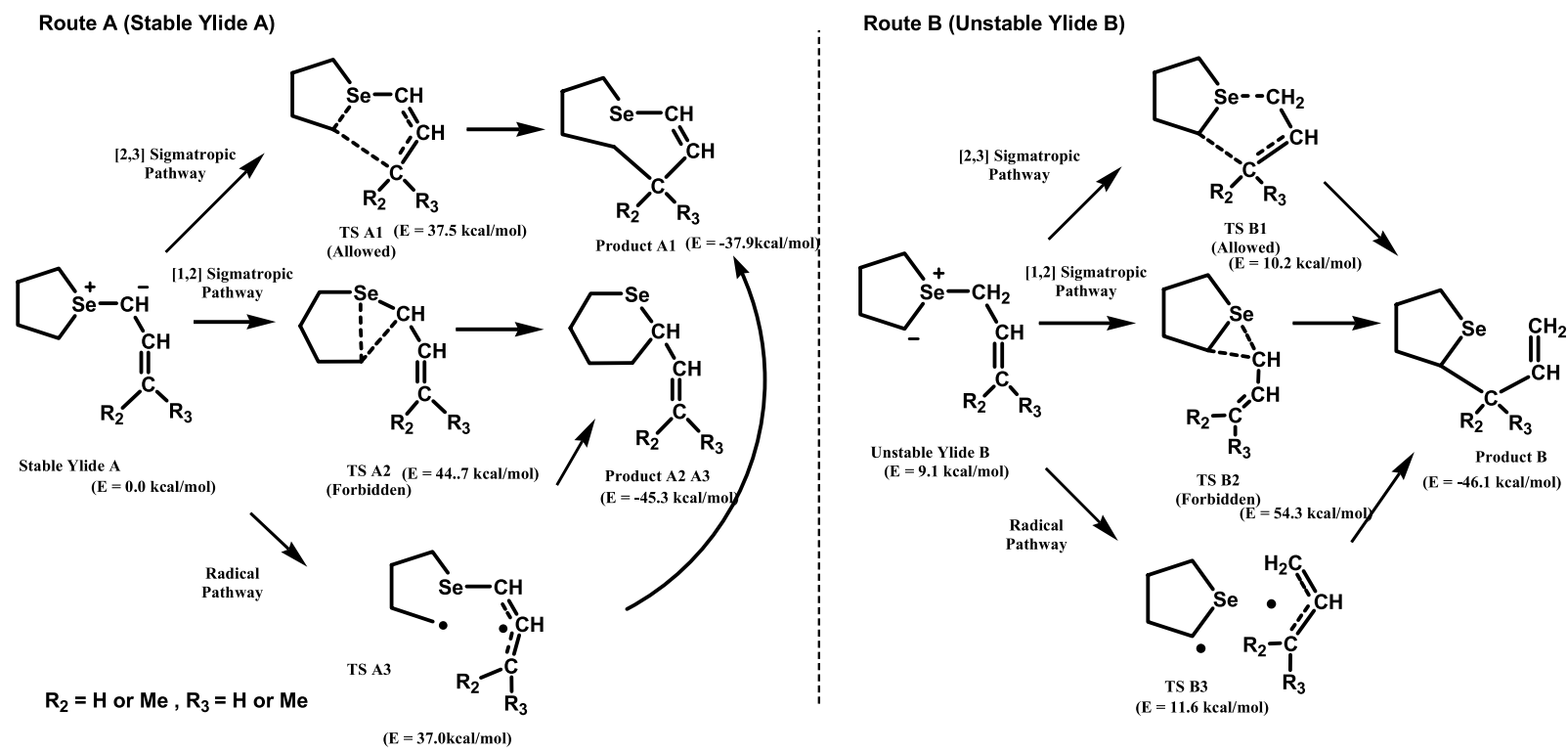

Scheme 8 
らかである. 次に，遷移状態を比較すると全ての遷移状態の 中で TSB1が $10.2 \mathrm{kcal} / \mathrm{mol}$ と最も小さくなっている.このこ とから，アリル基を有するセレノニウム塩の反応はベンジル 基を有するセレノニウム塩と同様にB RouteのイリドBから TSB1 経由した [2,3]-Sigmatropyの反応が有利であると考 えられる。この場合，ラジカル開裂の遷移状態は僅かではあ るが [2,3]-Sigmatropy経路のエネルギーより高くなる傾向 があることが分かる.

\section{4 結 論}

本研究ではベンジル基，4-メチルベンジル基，アリル基, メチル置換アリル基を有するセレノニウ塩の電解還元反応に より発生したイリドの反応としてオニウム塩単独の時にセレ ノニウム塩からの Sommelet-Hauser 型の転位反応が起こる 事を見出した。これに反し， $\mathrm{p}$-位に電子吸引基であるシアノ 基，ニトロ基を置換したベンジル基を有するセレノニウム塩 においてはベンズアルデヒドの存否に係わらず電解還元によ り生成するラジカル中間体からベンジルラジカルが開裂して 再結合したビベンジル誘導体のみが得られた。また，強い電 子吸引基であり安定なイリドを与えると考えられるエトキシ カルボニルメチル基を有するセレノニウム塩はカルベン中間 体が生成し，その二量体，三量体が得られることが明らかと なった。また，ベンズアルデヒドとのCorey-Chaykovsky 反 応によりイリドが生成されていることを確認し，この反応に おいては選択的に安定イリドAからのエポキシドおよびアル コール生成物が得られることを見出した，しかしこの時，置 換ベンジル基の-CN 基および- $\mathrm{NO}_{2}$ 基を有するセレノニウム 塩においてはラジカルからのカップリング生成物を選択的に 与えることが明らかとなった。

ベンジル基およびアリル基を有するセレンイリドから転位 の反応機構について，B3LYP密度汎関数法による理論計算

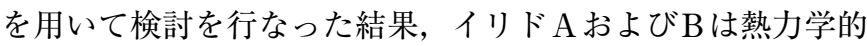
な選択性はなく平衡であると考えられ，遷移状態においては イリドBを経由するB routeのTSB1のエネルギーが全ての 遷移状態の中で最も小さく安定であることが明らかとなった. このことから，反応はイリドBから TSB1を経由した $[2,3]$ Sigmatropy 経路での反応が有利である事が判明した.

本研究において各種置換セレノニウム塩から電解還元法に より発生させたイリドからの反応が明らかとなり, そして置 換ベンジル基およびアリル基を有するセレンイリドからの転 位の反応経路を計算により解明した.

\section{文 献}

1) B. M. Trost and L. S. Melvin, Jr. Sulfur Ylides, Academic Press New York (1975).

2) E. Block, Reactions of Organosulfur Compounds, p.91, Academic Press New York (1978).

3) S. Oae, Yuuki Iou Kagaku (Reaction Mechanism) p.405 Tokyo Kagakudouzinn (1982) [in Japanese].

4) S. Oae, Yuuki Iou Kagaku (Synthetic Reaction) p.247 Tokyo Kagakudouzinn (1982) [in Japanese].

5) K. Makita, F. Ando, and J. Koketsu, Nipponn Kagaku Kaisi, 573 (2001).

6) Y. Okazaki, F. Ando, and J. Koketsu, Bull. Chem. Soc. Jpn., 76, 2155 (2003).

7) Y. Okazaki, F. Ando, and J. Koketsu, Bull. Chem. Soc. Jpn., 77, 1987 (2004).

8) Y. Okazaki, A. Takeuchi, F. Ando, and J. Koketsu, Electrochemistry, 73, 798 (2005).

9) Y. Oazaki, A. Takeuchi, F. Ando, and J. Koketsu, Electrochemistry, 73, 758 (2006).

10) Y. Okazaki, T. Asai, F. Ando, and J. Koketsu, Chem. Lett., 35, 98 (2006).

11) Y. Okazaki, F. Ando, and J. Koketsu, Memories of College of Engineering, Chubu University, 42, 87 (2006).

12) Gaussian 03, Revision B.05, M. J. Frisch, G. W. Trucks, H. B. Schlegel, G. E. Scuseria, M. A. Robb, J. R. Cheeseman, J. A. Montgomery, Jr., T. Vreven, K. N. Kudin, J. C. Burant, J. M. Millam, S. S. Iyengar, J. Tomasi, V. Barone, B. Mennucci, M. Cossi, G. Scalmani, N. Rega, G. A. Petersson, H. Nakatsuji, M. Hada, M. Ehara, K. Toyota, R. Fukuda, J. Hasegawa, M. Ishida, T. Nakajima, Y. Honda, O. Kitao, H. Nakai, M. Klene, X. Li, J. E. Knox, H. P. Hratchian, J. B. Cross, C. Adamo, J. Jaramillo, R. Gomperts, R. E. Stratmann, O. Yazyev, A. J. Austin, R. Cammi, C. Pomelli, J. W. Ochterski, P. Y. Ayala, K. Morokuma, G. A. Voth, P. Salvador, J. J. Dannenberg, V. G. Zakrzewski, S. Dapprich, A. D. Daniels, M. C. Strain, O. Farkas, D. K. Malick, A. D. Rabuck, K. Raghavachari, J. B. Foresman, J. V. Ortiz, Q. Cui, A. G. Baboul, S. Clifford, J. Cioslowski, B. B. Stefanov, G. Liu, A. Liashenko, P. Piskorz, I. Komaromi, R. L. Martin, D. J. Fox, T. Keith, M. A. Al-Laham, C. Y. Peng, A. Nanayakkara, M. Challacombe, P. M. W. Gill, B. Johnson, W. Chen, M. W. Wong, C. Gonzalez, and J. A. Pople, Gaussian, Inc., Pittsburgh PA, 2003.

13) K. Makita, F. Ando, Y. Ninomiya, and J. Koketsu, Nipponn Kagaku Kaisi, 470 (1998). 